\title{
Analysis of wetland uses by Common mynas (Acridotheres tristis) in the urban environment of Antananarivo, Madagascar
}

\author{
Lalatiana O. Randriamiharisoal, Hajanirina \\ Rakotomananal
}

\section{Correspondence:}

Lalatiana O. Randriamiharisoa

Zoology and Animal Biodiversity Department, Faculty of Science, University of Antananarivo, BP 906, Antananarivo 101, Madagascar Email: r.5tio@yahoo.fr

\begin{abstract}
The importance of wetlands as habitat and breeding grounds for waterfowls is recognized and has been extensively studied, but their role in regulating and maintaining ecosystems is less well documented. The use of wetlands by invasive species such as Common myna (Acridotheres tristis), considered as one of the 100 worst invasive species in the world, is largely unknown. Therefore, the Common mynas could have an influence on the occupation of native water bird species. The objectives of this study were to assess Common myna's (1) population size, (2) spatial occupation and (3) characteristics of foraging and roosting sites. Three urban wetlands in Antananarivo were studied: the Tsarasaotra Park, a private site classified as a Ramsar site, the Tsimbazaza Zoological and Botanical Park in the city center, and an area near the Ikopa River, close to the SOCOBIS biscuit factory. In total, 6196 Common mynas were counted with an estimated 7.9 individuals per hectare around the roosting sites. Vigilance and foraging behaviors were less observed when individuals were at a higher stratum, with communication and resting being the most observed behaviors at this level. Only $5.6 \%$ of wetlands are used during the day as foraging areas and $1.4 \%$ as roosting sites at night, where Common mynas cohabitate with herons and egrets. Finally, the environmental variables collected revealed that Common mynas favor wetlands with tall, wide trees, located far from human disturbance.
\end{abstract}

\section{RÉSUMÉ}

L'importance des zones humides en tant qu'habitat et site de reproduction pour les oiseaux d'eau est reconnue et a été abondamment étudiée. Cependant, le rôle des oiseaux d'eau dans la régulation et le maintien d'écosystème est moins bien documenté. Particulièrement l'utilisation des zones humides par des espèces envahissantes telles que le Martin triste (Acridotheres tristis), une des 100 pires espèces envahissantes dans le monde, reste peu étudiée. Le Martin triste pourrait avoir une influence et un impact par son occupation et son comportement envahissant sur les oiseaux d'eau autochtones. Afin d'évaluer la taille de la population du Martin triste, son utilisation et occupation spatiale, ainsi que les caractéristiques écologiques de ses zones d'alimentation et de dortoir, trois zones humides du milieu urbain d'Antananarivo ont été étudiées. II s'agit du Parc de Tsarasaotra, un site privé classé RAMSAR, le Parc Zoologique et Botanique de Tsimbazaza dans le centre-ville, et une zone située à proximité de la rivière Ikopa, près de I'usine de fabrication de biscuits SOCOBIS. Un nombre de 6196 observations de Martins tristes ont été réa- lisées et l'abondance des populations a été estimée à 7.9 individus par hectare autour des dortoirs. Les observations ont aussi révélé que le Martin triste réduit certains comportements tels que la vigilance et l'alimentation lorsqu'il est à une hauteur plus élevée et privilégie alors des comportements de communication et de repos. II utilise 5,6\% des zones humides pendant la journée en tant que site de nourrissage et $1,4 \%$ pendant la nuit comme dortoir, où il cohabite avec des hérons et des aigrettes. Les varia-bles environnementales récoltées sur les sites ont révélé que le Martin triste privilégie les zones humides situées loin des perturbations humaines et présentant de grands arbres à diamètre important.

\section{INTRODUCTION}

Globally, wetlands play an important role in supporting biodiversity (Nummi et al. 2013) and harboring large populations of birds (Mitchell 1992, Dugan 1993, Razafimanjato et al. 2015). Unfortunately, wetlands remain among the most threatened ecosystems in the world (Secrétariat de la Convention de Ramsar 2013) and their destruction is likely to continue (Chari et al. 2003, Fraser and Keddy 2005). Drainage, dewatering, pollution and overexploitation of resources are the most common threats (Sécretariat de la Convention de Ramsar 2013) and cause degradation of wetlands that could also affect waterfowl species (Rajpar and Zakaria 2011).

The introduction of alien invasive species could pose a threat to native species and global ecosystems (Sala et al. 2000), including wetlands. According to the International Union for Conservation of Nature, invasive species are "animals, plants or other organisms introduced by man into places out of their natural range of distribution, where they become established and disperse, generating a negative impact on the local ecosystem and native species" (Global 


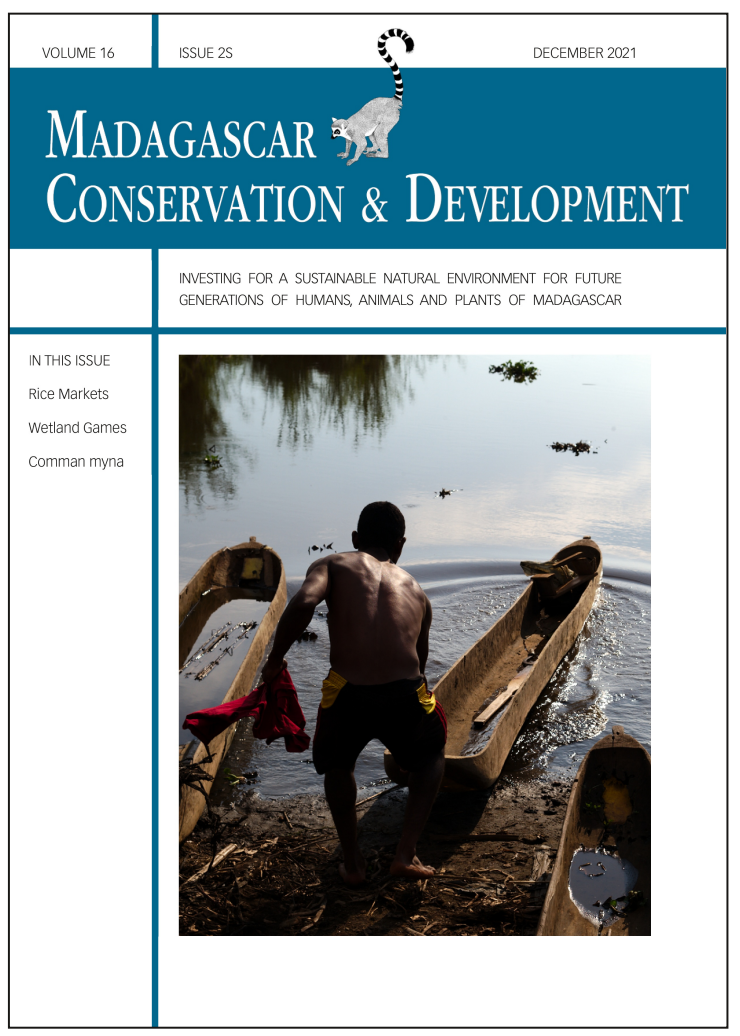

Madagascar Conservation \& Development is the journal of Indian Ocean e-Ink. It is produced under the responsibility of this institution. The views expressed in contributions to MCD are solely those of the authors and not those of the journal editors or the publisher.

All the Issues and articles are freely available at https://www.journalmcd.com

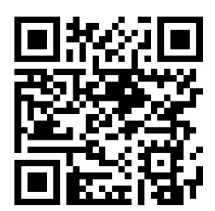

Contact Journal MCD

info@journalmcd.net for general inquiries regarding MCD funding@journalmcd.net to support the journal

Madagascar Conservation \& Development Institute and Museum of Anthropology

University of Zurich

Winterthurerstrasse 190

CH-8057 Zurich

Switzerland



Indian Ocean e-Ink

Promoting African Publishing and Education

www.ioeink.com

Missouri Botanical Garden (MBG)

Madagascar Research and Conservation Program

Missouri Botanical Garden

BP 3391

Antananarivo, 101, Madagascar 
Invasive Species Database 2018). The Common myna Acridotheres tristis is native to Asia and has an extremely large range; its conservation status is Least Concern within its native range. The Common myna is considered an alien invasive species in several places where it has been introduced such as in Hawaii, the Middle East, South Africa, Israel, North America, Europe, New Zealand and various oceanic islands such as the Seychelles and Madagascar (Martin 1996).

The Common myna, originating from Southeast Asia (Feare and Craig 1998), is known as one of the 100 worst invasive species in the world (Lowe et al. 2000). On Fregate Island in the Seychelles, it has been shown that it is a serious threat to endemic bird species, including to the endangered Zosterops modestus (Henriette and Rocamora 2011) and Copsychus sechellarum (Canning 2011). The Common myna has also been shown to be a predator of the eggs and chicks of Terpsiphone corvina on Denis Island in the Seychelles (Feare 2010).

The Common myna was introduced to eastern Madagascar from Reunion Island in 1875 (Decary 1962) to eliminate locusts that attack crops (Vinson 1867, Milon 1951, Ali 2002). Since the beginning of the millennium, the species has been encountered throughout Madagascar, particularly in urban, rural and open areas, including the city of Antananarivo (Hawkins and Goodman 2003). Goodman and Hawkins (2008) suggested that a proliferation of this species could represent an important competitor for native bird species. However, this has never been extensively studied in Madagascar, despite its potential to cause an ecological catastrophe (Raherilalao and Goodman 2011).

Madagascar has a unique avian composition (Raherilalao and Goodman 2011). Efforts to conserve this avifauna are often focused on bird species found in pristine forests (Haslem and Bennett 2008) and waterfowl in wetlands (e.g., Rabearivony et al. 2008, Barratt et al. 2009, Roux and Bejoma 2009, Pruvot et al. 2018). The wetlands of the island host a great population of waterfowl, many of which are endangered or heavily threatened (Rabarisoa 2001). Eighteen species of birds are found in lakes, marshes, rivers and mangroves; amongst them, four species of ducks (Anatidae) highly dependent on these areas (Langrand and Wilmé 1993, Rene de Roland et al. 2009). The most studied wetlands in Madagascar are Lake Alaotra on the eastern slope of the island, Lake Itasy to the West, Lake Kinkony in the Northwest, Lake Ihotry and Lake Tsimanampetsotsa in the Southwest (e.g., Zicoma 1999, Andriamasimanana et al. 2013, Randriamiharisoa et al. 2015, Bamford et al. 2017). In Antananarivo, several types of wetlands are encountered, including swamps, extensive lakes (Mandroseza, Anosy, Masay, Tsimbazaza, Tsarasaotra, etc.), as well as rivers such as the Ikopa; they constitute the wetlands of the capital city and its immediate surroundings (Milon 1949, Malzy 1967, Bamford et al. 2017).

Over the years, several studies have been conducted on the wetlands in Antananarivo and its surroundings (Milon 1949, Malzy 1967, Wilmé and Jacquet 2002, Razafimanjato et al. 2007, Raherilalao and Goodman 2011), but few studies have focused on the uses of these wetlands by invasive alien bird species such as the common mynas. The objective of this study is to assess the current situation of this species and to estimate its impact or influence on the indigenous waterfowl. To better understand how the Common myna is using the wetlands, this study has estimated: (i) the Common myna population size, (ii) the spatial occupation of bird species using the wetlands, and (iii) the characteristics of foraging and roosting sites.

\section{METHODS}

STUDY SITE. This study was mainly conducted in Antananarivo, the economic and political capital of Madagascar, in the Analamanga Region (E047 $\left.31^{\prime}, \mathrm{S} 18^{\circ} 55^{\prime}\right)$. Three wetlands were selected where the Common myna has established roosting sites (Figure 1).

The first site (Site 1), Tsarasaotra ( $\left.\mathrm{S} 18^{\circ} 52^{\prime}, \mathrm{E} 047^{\circ} 32^{\prime}\right)$, is located in the north-eastern part of Antananarivo. It is also known as Alarobia, which is the name of the neighborhood (Malzy 1967). Tsarasaotra was the first private site classified in the Ramsar Convention on Wetlands on 9 May 2005. The site gives protection to several populations of breeding waterfowl (Wilmé and Jacquet 2002, Dodman and Diagane 2003). The park covers 27 hectares and is surrounded by a tamboho (old traditional wall), and further includes two shallow lakes, one with a central island. This central island has become a refuge for several species of Malagasy waterfowl. The vegetation of Tsarasaotra is composed of trees, shrubs, grasslands and aquatic vegetation. The dominant tree species near and at the roost site are Pinus sp., Cryptocarya sp., Syzygium cuminii and Melia azedarach. Bamboos, Cyperus spp. and Juncus sp. cover the edges of the two lakes and the central islet. Over the last 30 years, breeding herons' droppings have killed the trees on the central islet (Ranoelison 2009); two standing dead trees are still visible. The remaining of the roost site consists of cultivation areas and buildings.

Site 2 is located in the center of the city, at the Parc Botanique et Zoologique de Tsimbazaza, the zoological garden of Antananarivo (E047 $32^{\prime}, \mathrm{S} 18^{\circ} 56$ '). It covers seven hectares of forest, lakes, grasslands, rock garden and build-up. The park protects several breeding colonies of waterfowl including on the bamboos fringing the biggest lake, on the trees of the small lake, and on the larger Eucalyptus sp. trees on the eastern site of the park. The common myna's roost is located in the trees of the small lake. The trees belong to Ficus sp., Cryptocarya sp. and Melia azedarach.

Site 3 is located in the south of Antananarivo, in the rural commune of Tanjombato, Tananarivokely (E047 $\left.32^{\prime}, \mathrm{S}^{\circ} 8^{\circ} 57^{\prime}\right)$. The Common mynas' roost is located on the property of the SOCOBIS (Société de Confiserie et Biscuiterie) factory. It is located along the Ikopa River. The property of the SOCOBIS factory is characterized mostly by built-up areas with a few wooded areas along the riverbank. Trees found there are Pinus sp., Cryptocarya sp., Spatodea sp., Jacaranda sp., Melia azedarach, and Casuarina sp. Finally, on the other side of river are small cultivation areas.

BIRD SURVEY. Five transects of $2 \mathrm{~km}$ long were established on the periphery of each site to estimate the abundance of Common mynas (Bibby et al. 2000). The transects were walked on foot at a constant speed of ca. $2 \mathrm{~km} / \mathrm{h}$, during which all the Common mynas present at a distance of $5 \mathrm{~m}$ were counted. Each transect was walked two or three times between 0700h and 1200h. To evaluate the number of Common mynas, direct counting was performed in the roosting sites in Tsarasaotra, Tsimbazaza and the Socobis site. The counting was carried out five times from $1700 \mathrm{~h}$ to 1800h during the month of April 2016, when the Common mynas returns to the roosts. The setting up took place at 16:30 when the roost was empty and when the Common mynas began to approach the roosting site. In Tsarasaotra, four people posted on the cardinal points of the roosts' periphery counted all the birds over a radius of $45^{\circ}$ on both sides. Because the roosts at Tsimbazaza and Socobis were smaller, only two people counted the Common my- 

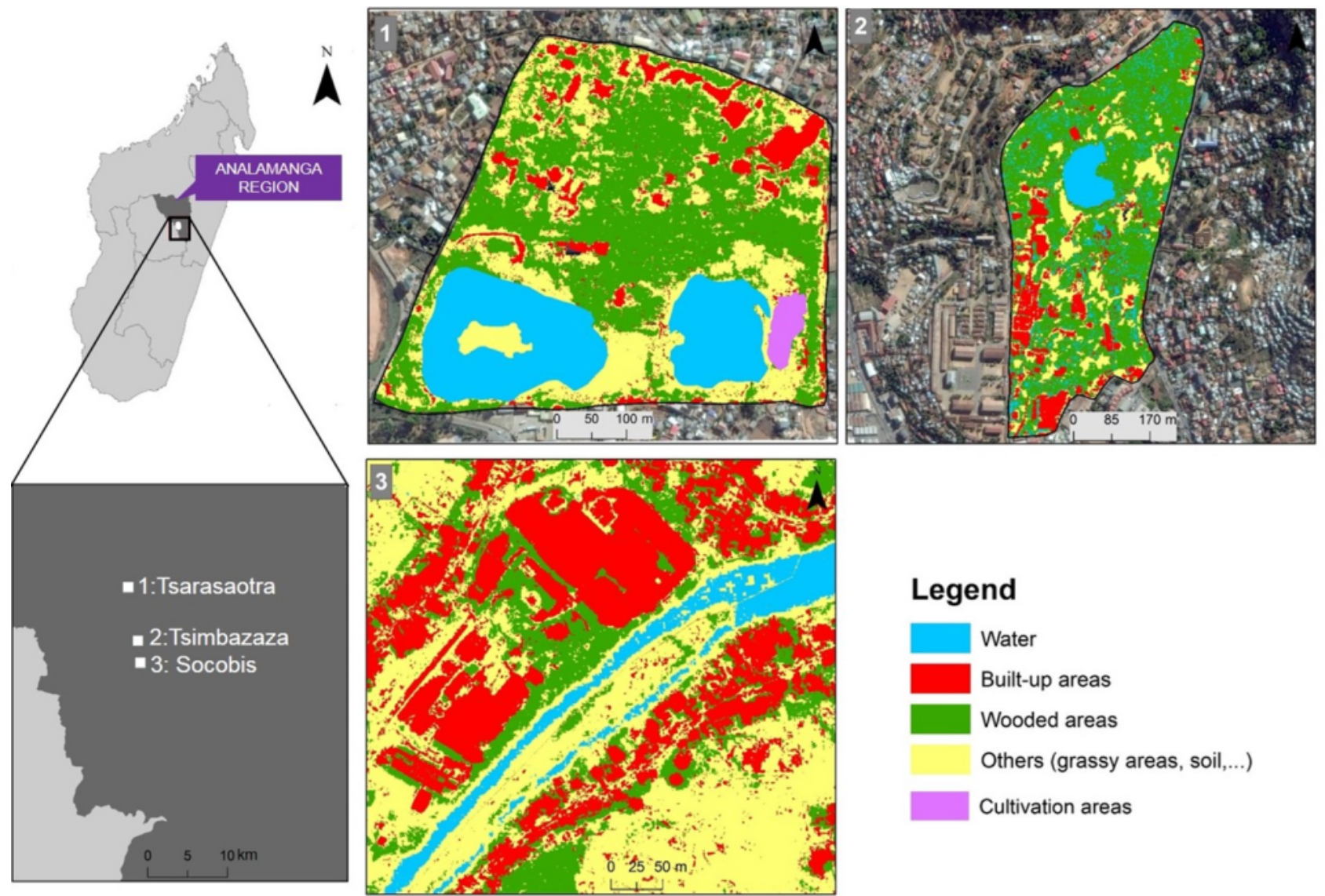

Figure 1. Location and description of study sites in the urban environment of Antananarivo, Madagascar, and occupation areas of Common mynas in the three wetlands.

nas on two opposite cardinal points of the periphery of the roosts. All individuals entering and leaving were counted to avoid duplicates.

The occupation of the wetlands and their use by the common mynas were described by direct observation with binoculars and a telescope. The distinction was made between horizontal occupation to apprehend the use of different habitats and vertical occupation to consider the height preferred by the birds in the trees. Points were taken with a GPS on the ground to distinguish the different areas according to bird activity, from feeding sites during the day to the roost during the night. The areas were subsequently delineated with a GIS. The vertical stratum was divided into four: (i) ground level with crop fields and grasslands; (ii) ground to $8 \mathrm{~m}$ high, mainly composed of bushes, shrubs and the surrounding wall; (iii) from 8 to $15 \mathrm{~m}$ with roofs of houses, poles and wires, and tree tops including in fruit trees; and (iv) strata from 15 to $20 \mathrm{~m}$ with buildings including the factory and apartments. Direct observation of the behavior of the Common myna took place from 0900 to $1200 \mathrm{~h}$ and from 1400 to $1600 \mathrm{~h}$. An individual was observed for five minutes, during which time each behavior was recorded and time was estimated for each activity. Five categories of behavior were defined: (i) communication with calls, song, head movements or play; (ii) feeding when birds were gleaning, jumping, actively seeking food, pecking or foraging in trees; (iii) grooming when removing parasites or preening feathers; (iv) resting when sleeping or sitting in the sun; and (v) vigilance when on the lookout or scrutinizing the surroundings. Observations could last less than five minutes if the birds left prematurely, or could occur on several strata if used within the five minutes.
ENVIRONMENT VARIABLES OF ROOSTS. Environmental variables were collected to identify the parameters inherent in the installation of the Common mynas' roost in a wetland. Several measurements of the trees in the roost were taken, including height, dbh (diameter at breast height) and crown cover of trees measured with decameters and clinometers. The woody cover is the surface of the crown of the tree projected vertically to the ground. It was measured with a decameter by considering the north-south and east-west axes of the projection. The distances between the roosts and surrounding features were measured, and the features were classified into two categories: (i) anthropogenic, such as road, factory, market, bus station, school, or parking lot; (ii) resources, such as water or food.

DATA ANALYSIS. The data were analyzed with the statistical

functions provided in Excel. The density of the Common myna population was calculated from the data collected on the transects and formulated in terms of number of individuals per ha. The number of individuals in each roost are the maximum numbers obtained from the iterative counts at the roosts. To characterize the behavior of the Common myna in the vertical strata, the durations of the various activities in each stratum were converted to percentages. To analyze the occupation of the Common myna in the horizontal zones, Google Earth pro images with a resolution of $5 \mathrm{~m}$ dated 12 July 2016 were used to estimate the surface of the feeding sites and the roosting sites. The images were cropped to extract the three study sites, Tsarasaotra, Tsimbazaza and Socobis. The study areas were classified according to different types of land use. The classification was subsequently launched on the maximum likelihood log on the Envi 4.5 software. Finally, the calculation of the Kappa coefficient was used to validate the classification, vectoriza- 
tion mapping and classification results. These manipulations allowed the conversion of raster images into polygons in a vectorial mode to facilitate the information management in ArcGIS (10.3). The environmental variables were processed with the statistical software SPSS 19.0. Crown cover was calculated from Ngom et al. (2013) to estimate tree density at the roost sites using the formula $<$ eqn1>:

\section{RESULTS}

POPULATION SIZE. During the study period, 224 Common mynas individuals were counted along the 15 transects in the

$$
C=\frac{\sum \pi\left(\frac{d_{m h}}{2}\right)^{2}}{S_{E}} \times 100
$$

\section{$\mathrm{C}=$ ligneous coverage in percentage; $\mathrm{d}_{\mathrm{mh}}=$ average diameter}

\section{of crown in meter, $\mathrm{S}_{\mathrm{E}}=$ sampling areas in ha}

three study sites, including 119 at Tsarasaotra, 55 at Tsimbazaza and 50 at Socobis, representing an average of 7.9 individuals/ha. A total of 6196 individuals were counted in the three roosts, including 4411 at Tsarasaotra, 90 at Tsimbazaza and 1695 at Socobis. The Common mynas usually arrived at the roosts by pairs, sometimes forming groups of eight to ten individuals. Once at the roosts, they made a lot of noise until nightfall, at which time their singing and calling stopped.

WETLAND OCCUPATION AND USE. The observations of 144 Common mynas individuals showed that the four vertical strata were used by the species (Table 1). The strata of 8 to 15 meters (31\%) and those at ground level (54\%) are mostly used during the day (Figure 2).

At ground level, foraging was the most commonly observer behavior, accounting for $45.3 \%$ of time spent on the ground (Table 1). The Common mynas ate arthropods, larvae and plant debris present in the soil. They would move and jump to disturb prey on the ground. This activity was alternated with vigilance behavior for Table 1: Percentage of time spent by the common myna in each layer per activity

\begin{tabular}{lllll}
\hline \multirow{2}{*}{ Behavior } & \multicolumn{4}{c}{ strata height } \\
\cline { 2 - 5 } & $0 \mathrm{~m}$ & $0-8 \mathrm{~m}$ & $8-15 \mathrm{~m}$ & $15-20 \mathrm{~m}$ \\
\hline Communication & $34.9 \%$ & $38.3 \%$ & $64.3 \%$ & $50.0 \%$ \\
Foraging & $45.3 \%$ & $21.5 \%$ & $14.3 \%$ & $0.0 \%$ \\
Grooming & $7.6 \%$ & $23.4 \%$ & $9.8 \%$ & $8.3 \%$ \\
Resting & $3.5 \%$ & $5.6 \%$ & $5.7 \%$ & $41.7 \%$ \\
Vigilance & $8.7 \%$ & $11.2 \%$ & $5.7 \%$ & $0.0 \%$ \\
\hline
\end{tabular}

$8.7 \%$ of time spent on the ground. Vigilance behavior includes lateral displacement to avoid potential predators (e.g., dogs). The stratum between 8 and $15 \mathrm{~m}$ was mainly used for communication (64.3\%), as well as for foraging (14.3\%) on fruit trees such as Morus sp., Ficus sp., Cryptocarya sp. and Melia azedarach, grooming $(9.8 \%)$, resting $(5.7 \%)$, and vigilance $(5.7 \%)$. Individuals frequently communicated during the day. To this end, one individual emitted a call or sang, and to answer, another individual either sang, moved or flew towards the first individual. It is also in this stratum that the nests were most often observed. The horizontal occupation is expressed by the area within which the Common mynas was observed for the study. Horizontal spatial analysis showed that wetlands are used both as foraging and roosting sites (Figure 3).

The three sites were used as roosts at night and as foraging sites during the day and at dusk. The roost of Tsarasaotra occupied an area of 0.27 ha, or $1.35 \%$ of the wooded area of site 1 . The roost of site 2 covered an area of 0.07 ha, or $1.40 \%$ of the wooded area of Tsimbazaza Park. In the Socobis site, the roost covered 0.08 ha. Trees in the study sites were also used as day roosts for about 15 Common mynas. Other species of birds such as Cattle egrets (Bulbucus ibis) and Dimorphic egrets (Egretta dimorpha) were also present in these roosts, and used them to perch temporarily, rest, or nest. The Common myna and the two species of egrets shared the space in the trees according to the height available above the branches serving as perch or as a support for the nests. The Dimorphic egrets is the larger of the three species, with a length of ca. 60 $\mathrm{cm}$, compared to ca. $50 \mathrm{~cm}$ for the Cattle egret and ca. $23 \mathrm{~cm}$ for the Common myna. The Dimorphic egret occupied the branches where few or no birds were already present, the Cattle egret perched on branches with a little less vertical space as compared to the branches where the Dimorphic egret perched, and the Common mynas were usually encountered in the most cluttered areas of the trees where the space between branches was limited. The

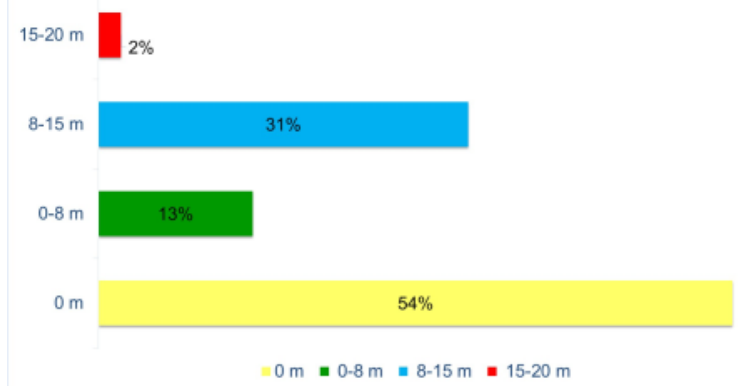

Figure 2. Use of the vertical layer by Common myna expressed by percentage of time spent in each layer.
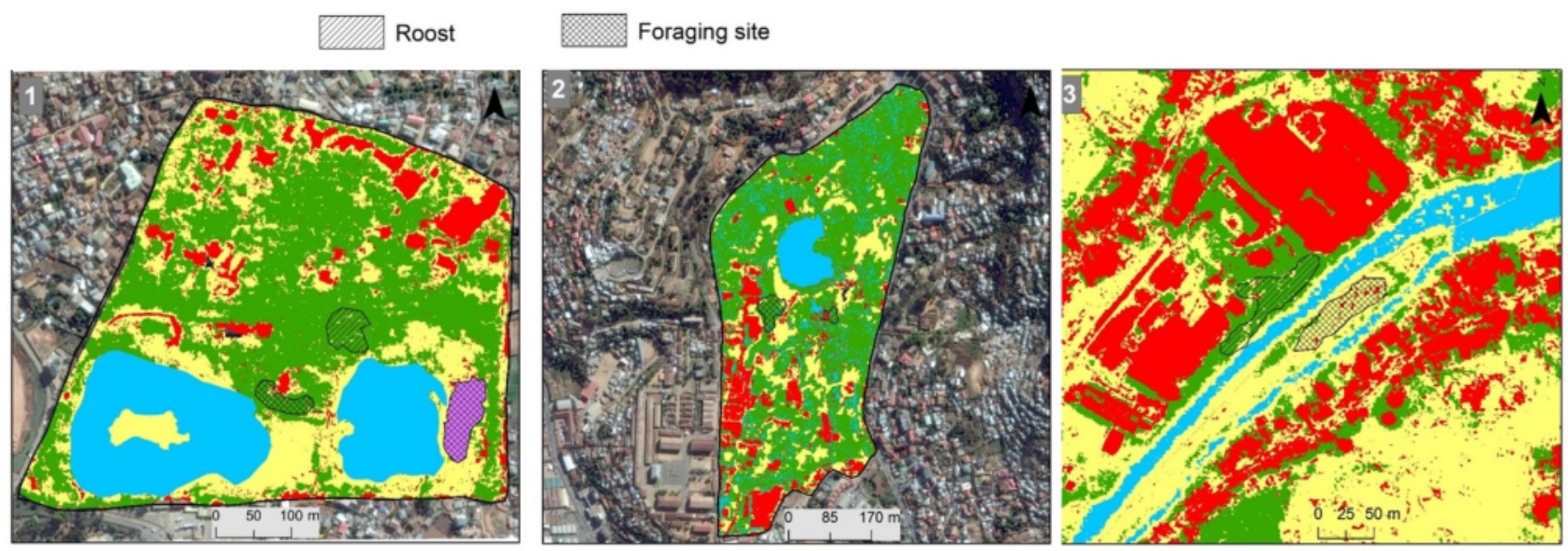

Figure 3. Roosting and foraging sites. 
Common mynas formed a dense roost in each tree with four to six individuals on each smaller branch, below the larger branches occupied by the egrets.

For feeding, the Common mynas occupied about 0.58 ha of a watercress field and 0.22 ha of an orchard in Tsarasaotra. In the watercress field, Common mynas fed on larvae and insects, and in the orchard, they fed on fruits of Syzygium cuminii and Melia azedarach. In Tsimbazaza, the foraging site was estimated at 0.28 ha, about $5.6 \%$ of the orchard surface. The Common mynas fed on fruits and seeds of Syzygium cuminii and Melia azedarach. These trees were also used as day roost. The foraging areas at Socobis had an area of 0.21 ha of cultivated fields in which Common mynas fed on insects and larvae. In the three sites, the Common mynas were encountered in groups of two to eight individuals when feeding, and were randomly distributed in the horizontal and vertical strata.

ENVIRONMENTAL VARIABLES. The inventory of nests around wetlands showed that out of the 15 nests identified in the three sites, 13 nests (86.7\%) had been built under the rooves of houses, one nest at Tsarasaotra had been constructed in a gutter and the last nest was in a cavity of a tree trunk in Tsimbazaza. Of the 13 nests built under rooves, nine were under a sheet roof (69.2\%) and four under tile rooves (30.8\%). The average height of the nests was $8.9 \pm 3.4 \mathrm{~m}$.

The diversity of the flora varied at each roost. It was limited to one species of Ficus sp. at the Tsimbazaza roost, versus a dozen species for the Tsarasaotra and Socobis roosts, with Pinus sp., Cryptocarya sp. and Syzygium cuminii common to both sites. The trees supporting the roosts had a high diameter, usually higher than $40 \mathrm{~cm}$ and up to more than $65 \mathrm{~cm}$, and a height of at least 12 $\mathrm{m}$ and up to $20 \mathrm{~m}$, with the exception of the small Ficus tree at Tsimbazaza, but having the densest crown cover (Table 2).

The roosts had different positions in the environment in the three studied sites, with varying distances to resources and anthropogenic disturbances (Table 3). Tsarasaotra sheltered the roost furthest from human disturbances with the greatest distance to the foraging site. The Tsimbazaza and Socobis roosts were close to foraging sites but Tsimbazaza was closer to anthropic disturbances (Table 3).

\section{DISCUSSION}

The inventory showed that the Common mynas are often encountered in pairs during the day and that they can go at least $2 \mathrm{~km}$ around their roosts. This could mean that the common myna live in pairs during the day as a strategy to avoid competition for access to resources. The results also show that the abundance of the species at site 1 is greater than at the other two sites, both around the roosting sites and at the roosts themselves. Tsarasaotra is a
Table 3. Human disturbance parameters of each roost expressed as distance from roost to features $(m)$.

\begin{tabular}{lccc}
\hline \multirow{2}{*}{ Features } & \multicolumn{3}{c}{ Distances to roosts (m) } \\
& Tsarasaotra & Tsimbazaza & Socobis \\
\hline Food resources & 200 & 30 & 30 \\
Water (lake or river) & 10 & 3 & 6 \\
Roads & 400 & 150 & 250 \\
Bus station & 400 & 150 & 600 \\
Car parking & 250 & 140 & 600 \\
Market or shopping center & 400 & 155 & 250 \\
School & 250 & & \\
Factory or industrial building & & & 80 \\
\hline
\end{tabular}

large private park with

few people and few disturbances as compared to the other two sites in the city center, with a relatively large park attracting many visitors at site 2, and a small area with industrial activities at site 3 .

The areas around sites 2 and 3 are less urbanized than the area around site 1 . The distribution of Common myna depends on its preference for urban habitats or habitation areas where food, shelter and nesting are more easily accessible (Old et al. 2014). This finding was confirmed by other authors, such as van Rensburg et al. (2009), Lowe et al. (2011) and Sol et al. (2012) and provides additional evidence that Common myna mainly live in urban areas with a high human population. As for the roosts, site 2 is less abundant than the other two sites. This is probably due to the presence of other bird species. Competition between Common Mynas, herons and egrets for branches to perch on might explain the low abundance of Common myna in site 2. However, the population of the capital city could increase over time. In this study, the Common myna occupied only 1.1 to $5.6 \%$ of the area of the feeding sites and $1.4 \%$ of the wooded area for the roosts. Elsewhere in the world, the species is known to nest one to three times a year (Markula et al. 2016), but we only observed it twice during this study. Human disturbances, either direct in the case of visitors at a site, or indirect such as industrial activities far from the sites, seem to limit the extension of the common myna population. The Common myna seems to favor the wetlands of the city and the quiet spaces with large trees to accommodate the roosts. Given its recent arrival in the capital city, it is still difficult to estimate whether the population has reached its maximum number or whether it is still increasing in an ecological niche not yet saturated.

The results also show that the Common myna spends a lot of time on the ground to feed. Elsewhere, it is known to feed on the ground (Griffin et al. 2013), mainly on arthropods and annelids (Jalil 1985, Kang 1989, Yap et al. 2002, Markula et al. 2016). Certain behaviors such as vigilance and feeding decrease when the species is at a higher height, particularly in the 8 to $15 \mathrm{~m}$ stratum that is preferred for nest construction. Vigilance behavior in lower strata could be explained by the threat of potential predators such as dogs, cats, Madagascar kestrel Falco newtoni, or people, even if the species has a certain tolerance to human presence (McGiffin et al.

Table 2. Ecological parameters of the roosts at the three study sites. (DBH = diameter of trunk or branches at an height of $1.5 \mathrm{~m}$ above ground, $\mathrm{H}$ max $=$ maximum height of tree, $\mathrm{C}=$ crown cover; repartition = number of trees of the species divided by the total number of trees in the roost, $\pm=$ standard deviation, $\mathrm{n}=\mathrm{sample}$ size)

\begin{tabular}{|c|c|c|c|c|c|c|}
\hline site & Family & Composition & Repartition & $\mathrm{DBH}(\mathrm{m})$ & $\mathrm{H} \max (\mathrm{m})$ & $\mathrm{C}$ \\
\hline \multirow[t]{3}{*}{ Tsarasaotra } & LAURACEAE & cryptocarya sp. & $19 \%$ & $52,6 \pm 15,7 n=16$ & $18,4 \pm 2,7 n=16$ & $50 \%$ \\
\hline & MYRTACEAE & Syzygium cuminii & $50 \%$ & & & \\
\hline & PINACEAE & Pinus sp. & $31 \%$ & & & \\
\hline Tsimbazaza & MORACEAE & Ficus sp. & $100 \%$ & $25,6 \pm 7,5 n=12$ & $8 n=1$ & $96 \%$ \\
\hline \multirow[t]{7}{*}{ Socobis } & BIGNONIACEAE & Jacaranda acutifolia & $7 \%$ & $41,7 \pm 23,4$ n=14 & $12,3 \pm 2,3 n=14$ & $83 \%$ \\
\hline & BIGNONIACEAE & Spatodea sp. & $43 \%$ & & & \\
\hline & CASUARINACEAE & Casuarina sp. & $7 \%$ & & & \\
\hline & CUPRESSACEAE & Cupressus sp. & $14 \%$ & & & \\
\hline & LAURACEAE & Cryptocarya sp. & $14 \%$ & & & \\
\hline & MELIACEAE & Melia azedarach & $7 \%$ & & & \\
\hline & PINACEAE & Pinus sp. & $8 \%$ & & & \\
\hline
\end{tabular}


2013). The communication behavior is more important in higher strata. This could be explained by the fact that the Common myna is more vigilant in the lower strata and therefore more discreet.

During this study, it should be noted that the Common myna cohabited in the three sites with other birds such as the Cattle egret and the Dimorphic egret. This cohabitation was only effective during the night and at the roost, and is therefore likely beneficial for the three species concerned. The Common myna would add density to the colony in each tree of the roost by occupying the spaces that the egrets cannot occupy. This increase in density could benefit the three species by them gaining in protection from wind and rain, for example. On the other hand, the Common myna could also threaten egrets by eating eggs or chicks, by transmitting parasites and diseases such as avian malaria (Caughley and Sinclair 1997, Lever 2005, Peacock et al. 2007), or attacking them, as the Common myna is known to be an aggressive bird (Holzapfel et al. 2006, Griffin 2008, Haythorpe et al. 2012). Also, the Common mynas seems to be present in more abundant numbers than egrets and herons during this study. However, this competition was not observed during this study.

The Common myna usually nests in tree cavities (Lowe et al. 2011), but in this study only one such nest was found, while the majority of nests were built under rooves. It is probable that the trees in the city have no suitable cavities to host a nest or that the rooves of houses are more favorable.

Floristic diversity does not appear to play a decisive role in the establishment of roosts of Common myna in Antananarivo, as in the case of Tsimbazaza there is only one species of Ficus. This result is consistent with what has been observed elsewhere (Tracey et al. 2007). Three other environmental variables for the location and density of roosts emerged from our three study sites: (i) tree height and diameter, (ii) proximity to a wetland, and (ii) human disturbance. According to a study by Yap et al. (2002), the location of a common myna roost depends on crown cover and proximity to feeding sites. Variables such as distance from human disturbances and distance to a wetland are also mentioned (Nee and Yeo 1993, Yap et al. 2002). The crown cover is low in site 1 but important in the other two sites, while the biggest colony of Common myna is in site 1. Therefore, the degree of disturbance seems to be the main factor limiting the size of the roosts; it is low in site 1, housing the largest roost.

\section{CONCLUSION}

Each type of habitat has specific environmental variables; habitat is defined by compromises between food, roost and protection against predators (Raherilalao and Goodman 2011). The three sites in this study provide not only suitable habitat for waterfowl but recently also for the Common myna. The Common myna uses the vertical and horizontal strata of wetlands as they offer roosts and feeding sites with crop fields and fruit trees. The Common myna would have adopted a specific strategy in Antananarivo by occupying the wetlands surrounded by trees, crops and houses, thus finding feeding places close to water, nesting sites in height, and roosts with little nocturnal disturbances. These results provide qualitative and quantitative information on the current situation of the Common mynas in Antananarivo city. Although they only represent a sample of the species' population, these will serve as a reference for future studies.

\section{ACKNOWLEDGEMENTS}

We thank the family Ranarivelo at Tsarasaotra, Mr Jean Luck Rado Ravoavy Randrianasolo, Chef of Bird division at Tsimbazaza Park, and Technical Director and Director of Socobis factory who always welcomed us at their site. We thank also Lucienne Wilmé, Amadou Ranirison and Ranja Andriantsoa for their support and their help. Special thanks go to Mr Jules Félix Randriamiharisoa, Mrs Odile Rakotomalala and my research assistants Simplice Razafindranaivo and Laza Harifetra Andrianandrianina for their help in the field.

\section{REFERENCES}

Ali, S. 2002. The Book of Indian Birds, 13th Edition, Oxford University Press, Oxford.

Andriamasimanana, R. H., Rasolomanana, E. H., Cameron, A. \& Ratsimbazafy, J. 2013. Étude des impacts écologiques du dynamisme spatio-temporel des habitats naturels sur la faune menacée du Complexe Zones Humides Mahavavy-Kinkony, Madagascar. Madagascar Conservation \& Development 8, 2 : 86-90. <https://doi.org/10.4314/mcd.v8i2.7>

Bamford, A. J., Razafindrajao, F., Young, R. P. and Hilton, G. M. 2017. Profound and pervasive degradation of Madagascar's freshwater wetlands and links with biodiversity. PLOS ONE 12, 8: e0182673. $<$ https://doi.org/ 10.1371/journal.pone.0182673>

Barratt, N., Lashaway, C., Rai, A., Molou, I., Kartchner, Z. and Holley, A. 2009. Urban avian population and possible heavy metal contamination at Parc Tsarasaotra, Alarobia, Antananarivo, Madagascar. Malagasy Nature 2: 167-172.

Bibby, C. J., Burgess, N. D. and Hill, D. A. 2000. Bird Census Techniques. Academic Press, London.

Canning, G., 2011. Eradication of the invasive Common myna, Acridotheres tristis, from Fregate Island, Seychelles. Phelsuma 19: 43-53.

Caughley, G. and Sinclair, A. R. E. 1994. Wildlife Ecology and Management. Blackwel Publishing, Cambridge, UK.

Chari, K. B., Abbasi, S. A. and Ganapathy, S. 2003. Ecology, habitat and bird community structure at Oussudu lake: towards a strategy for conservation and management. Aquatic Conservation: Marine and Freshwater Ecosystems 13, 5: 373-386. <https://doi.org/10.1002/aqc.572>

Decary, R. 1962. Sur des introductions imprudentes d'animaux Mascareignes et à Madagascar. Bulletin de Muséum national d'Histoire naturelle, série 2, 34, 5 : 404-407.

Dodman T. \& Diagane H.C. 2003. Les Dénombrements d'Oiseaux d'Eau en Afrique, 1999, 2000, 2001 et 2003. Impression Saint-Paul, Dakar, Sénégal.

Dugan, P. 1993. Wetlands in Danger: A World Conservation Atlas. Oxford University Press, New-York.

Feare, C. J. 2010. The use of Starlicide $\AA$ in preliminary trials to control invasive common myna Acridotheres tristis populations on St Helena and Ascension Islands, Atlantic Ocean. Conservation Evidence 7: 52-61. Available <https:// www.conservationevidence.com/individual-study/2317>

Feare, C. J. and Craig, A. 1998. Starlings and Mynas. Cristhopher Helm, London.

Fraser, L. H. and Keddy, P. A. 2005. The World's Largest Wetlands: Ecology and Conservation. Cambridge University Press, Cambridge, UK.

Global Invasive Species Database. 2018. Species profile: Acridotheres tristis. Downloaded 20 July 2018 <http://www.iucngisd.org/gisd/species.php?SC=108 on 25-11-2018>

Goodman, S. M. \& Hawkins, A. F. A. 2008. Les oiseaux. Dans: Paysages Naturels et Biodiversité de Madagascar. S. M. Goodman (ed.), pp 383-434. Muséum national d'Histoire Naturelle, Paris.

Griffin, A. S. 2008. Social learning in Indian mynahs, Acridotheres tristis: the role of distress calls. Animal Behavior 75, 1: 79-89. <http://dx.doi.org/10.1016/j.anbehav.2007.04.008>

Griffin, A. S., Lermite, F., Perea, M. and Guez, D. 2013. To innovate or not: contrasting effects of social groupings on safe and risky foraging in Indian mynahs. Animal Behavior 86, 6: 1291-1300. <https://doi.org/10.1016/j.anbehav.2013.09.035>

Haslem, A. and Bennett, A. F. 2008. Countryside elements and the conservation of birds in agricultural environments. Agriculture, Ecosystems \& Environment 125, 1-4: 191-203. <https://doi.org/10.1016/j.agee.2008.01.001> 
Hawkins, A. F. A. \& Goodman, S. M. 2003. Introduction to the birds. In: The Natura History of Madagascar. S. M. Goodman and J. P. Benstead (eds.), pp 10191044. The University of Chicago Press, Chicago.

Haythorpe, K. M., Sulikowski, D. and Burke, D. 2012. Relative levels of food aggression displayed by Common mynas when foraging with other bird species in suburbia. Emu 112, 2: 129-136. <http://dx.doi.org/10.1071/MU11046>

Henriette, E. and Rocamora, G. 2011. Comparative use of three methods for estimating the population size of a transferred island endemic: the endangered Seychelles White-eye Zosterops modestus. Ostrich 82, 2: 87-94. <https:// doi.org/10.2989/00306525.2011.603462>

Holzapfel, C., Levin, N., Hatzofe, O. and Kark, S. 2006. Colonisation of the Middle East by the invasive Common Myna Acridotheres tristis L., with special reference to Israel. Sandgrouse 28, 1: 44-51. Available <https://goo.gl/nzWdd6>

Jalil, A. K. 1985. Feeding ecology of two species of mynas (Sturnidae: (Acridotheres sp.) in Singapore. Thesis, National University of Singapore, Singapore. Accessed on 03 Décembre 2018. <https://g0o.gl/RnX8X0>

Langrand, O. \& Wilmé, L. 1993. Protection des zones humides et conservation des espèces d'oiseaux endémiques de Madagascar. In: R.T. Wilson (ed.). Proceedings of the 8th Pan-African Ornithological Congress: Birds and the African Environment. Musée Royal de l'Afrique Centrale, Tervuren Annalen 268: 201208.

Lever, C. 2005. Naturalised Birds of the World. T. \& A. D. Poyser, London.

Lowe, S., Browne, M., Boudjelas, S. and De Poorter, M., 2000. 100 of the World's Worst Invasive Alien Species: a selection from the global invasive species database. The Invasive Species Specialist Group (ISSG) a specialist group of the Species Survival Commission (SSC) of the World Conservation Union (IUCN). Available <http://www.issg.org/booklet.pdf >

Lowe, K. A., Taylor, C. E. and Major, R. E. 2011. Do Common mynas significantly compete with native birds in urban environments? Journal of Ornithology 152 909-921. <http://dx.doi.org/10.1007/s10336-011-0674-5>

Malzy, P. 1967. La héronnière d'Alarobia (Tananarive). Oiseau et Revue Française d'Ornithologie 37: 122-142.

Markula, A., Hannan-Jones, M. and Csurhes, S. 2016. Invasive Animal Risk Assessment. Indian Myna Acridotheres tristis. Department of Agriculture and Fisheries, Biosecurity Queensland, Queensland Government, Australia. Available $<\mathrm{https}: / / g 00 . \mathrm{gl} / \mathrm{hd} 89 \mathrm{kY}>$

Martin, W. K. 1996. The current and potential distribution of the Common Myna Acridotheres tristis in Australia. Emu 96: 166-173. <http://dx.doi.org/10.1071/ MU9960166>

McGiffin, A., Lill, A., Beckman, J. and Johnstone, C. P. 2013. Tolerance of human approaches by Common mynas along an urban-rural gradient. Emu 113, 2: 154$160<$ http://dx.doi.org/10.1071/MU12107>

Milon, P. 1949. Les crabiers de la campagne de Tananarive. Le Naturaliste Malgache $1: 3-9$

Milon, P. 1951. Sur la distribution du Martin à Madagascar. Le Naturaliste Malgache 3: 67-73.

Mitchell, J. G. 1992. Our disappearing wetlands. National Geographic 182, 4: 3-46.

Nee, K. and Yeo, V.Y.Y. 1993. Roost site selection and the waking and roosting behaviour of mynas in relation to light intensity. Malayan Nature Journal 46: 255263.

Ngom, D., Fall, T., Sarr, O., Diatta, S. \& Akpo, L. E. 2013. Caractéristiques écologiques du peuplement ligneux de la réserve de biosphère du Ferlo (Nord Sénégal). Journal of Applied Biosciences 65: 5008-5023. <https://doi.org/10.4314/ jab.v65i0.89644>

Nummi, P., Paasivaara, A., Suhonen, S. and Pöysä, H. 2013. Wetland use by brood earing female ducks in a boreal forest landscape: the importance of food and habitat. Ibis 155, 1: 68-79. <https://dx.doi.org/10.1111/ibi.12013>

Old, J. M., Spencer, R. J. and Wolfenden, J. 2014. The Common myna (Sturnus tristis) in urban, rural and semi-rural areas in Greater Sydney and its surrounds. Emu 114, 3: 241-248. <https:// doi.org/10.1071/MU13029>

Peacock D. S., Van Rensburg, B. J. and Robertson, M. P. 2007. The distribution and spread of the invasive alien Common myna, Acridotheres tristis L. (Aves: Sturnidae), in southern Africa. Southern Africa Journal of Science 103, 11-12: 465-473. Available <http://ref.scielo.org/cnnq9g>
Pruvot, Y. Z., René de Roland, L.-A., Razafimanjato, G., Rakotondratsima, M. P. H., Andrianarimisa, A. and Thorstrom, R. 2018. Nesting biology and food habits of the endangered Sakalava Rail Amaurornis olivieri in the Mandrozo Protected Area, western Madagascar. Ostrich 89, 2: 109-115. <https://doi.org/ $10.2989 / 00306525.2017 .1317296>$

Rabarisoa, R. 2001. Variation de la population des oiseaux d'eau dans le complexe des lacs de Manambolomaty, un site Ramsar de Madagascar. Ostrich 72, Supplement 15: 83-87. <https://doi.org/10.2989/00306520109485333>

Rabearivony, J., Fanameha, E, Mampiandra, J. and Thorstom, R. 2008. Taboos and social contracts: Tools for ecosystem management - lessons from the Manambolomaty Lakes RAMSAR site, western Madagascar. Madagascar Conservation \& Development 3, 1: 7-16. <https://doi.org/10.4314/ mcd.v3i1.44130>

Raherilalao, M. J. \& Goodman, S. M. 2011. Histoire Naturelle des Familles et SousFamilles Endémiques d'Oiseaux de Madagascar, Association Vahatra. Antananarivo.

Rajpar, M. N. and Zakaria, M. 2011. Bird species abundance and their correlationship with microclimate and habitat variables at natural Wetland Reserve, Peninsular Malaysia. International Journal of Zoology: \#758573. <https://doi.org/ $10.1155 / 2011 / 758573>$

Randriamiharisoa, L. O., Rakotondravony, D., Raherilalao, M. J., Ranirison, A., Wilmé, L. and Ganzhorn, J. U. 2015. Effects of transhumance route on the richness and composition of bird communities in Tsimanampesotse National Park. Madagascar Conservation \& Development 10, 3S: 110-115. <https://doi.org/ 10.4314/mcd.v10i3.2>

Ranoelison, V. T. 2009. Proposition d'aménagement du territoire d'Anatidae et d'Ardeidae dans le site Ramsar Tsarasaotra. Mémoire de fin d'étude en vue de l'obtention du certificat d'aptitude pédagogique de l'école normale (CAPEN). Université d'Antananarivo, Antananarivo. Accessed 12 November 2016. <http://biblio.univ-antananarivo.mg/theses2/>

Razafimanjato, G., Sam, T. S. and Thorstrom, R. 2007. Waterbird monitoring in the Antsalova Region, western Madagascar. Waterbirds 30, 2: 441-447. <https:// www.jstor.org/stable/4501851>

Razafimanjato, G., Razafimahatratra, B., Randrianjafiniasa, D. \& Andriamalala, T. 2015 Suivi de la communauté aviaire aquatique dans la Nouvelle Aire Protégée Mandrozo, Ouest de Madagascar. Malagasy Nature 9: 49-57.

Rene de Roland, L.-A., Thorstrom, R., Razafimanjato, G., Rakotondratsima, M. P. H., Andriamalala, T. R. A. and Sam T. S. 2009. Surveys, distribution and current status of the Madagascar Harrier Circus macrosceles in Madagascar. Bird Conservation International 19, 4: 309-322. <https://doi.org/10.1017/ S095927090900817X>

Roux, F. \& Bejoma, B. 2009. Les populations d'oiseaux aquatiques en périphérie d'une ferme de crevetticulture (OSO Farming). Malagasy Nature 2: 94-110.

Sala, O. E., Chapin, F. S., Armesto, J. J., Berlow, E., Bloomfield, J., et al. 2000. Global biodiversity scenarios for the year 2100. Science 287, 5459: 1770-1774. <https://doi.org/10.1126/science.287.5459.1770>

Secrétariat de la Convention de Ramsar. 2013. Le Manuel de la Convention de Ramsar : Guide de la Convention sur les Zones Humides (Ramsar, Iran, 1971), 6e édition. Secrétariat de la Convention de Ramsar, Gland, Suisse.

Sol, D., Bartomeus, I. and Griffin, A. S. 2012. The paradox of invasion in birds: competitive superiority or ecological opportunism? Oecologia 169: 553-564. $<$ https://doi.org/10.1007/s00442-011-2203-x>

Tracey, J., Bomford, M., Hart, Q., Saunders, G. and Sinclair, A. R. E. 2007. Managing Bird Damage to Fruit and Other Horticultural Crops. Bureau of Rural Sciences, Canberra. Available <https://goo.gl/Sdtra1>

Van Rensburg, B. J., Peacock, D. S. and Robertson, M. 2009. Biotic homogenization and alien bird species along an urban gradient in South Africa. Landscape and Urban Planning 923: 233-241. < < chttp://dx.doi.org/10.1016/j.landurbplan.2009.05.002>

Vinson, A. 1867. Le martin (Acridotheres tristis, Vieil.). Son utilité pour les pays exposés à l'invasion des sauterelles. Société Impériale Zoologique d'Acclimatation 2, 4: 181-189.

Wilmé, L. and Jacquet, C. 2002. Census of water birds and herons nesting at Tsarasaotra (Alarobia), Antananarivo, during the second semester of 2001. Working Group on Birds in the Madagascar Region Newsletter 10, 1:14-21. 
Yap, C., Sodhi, N. S. and Brook, B. W. 2002. Roost characteristics of invasive mynas in Singapore. Journal of Wildlife Management 66: 1118-1127. <https://doi.org/ $10.2307 / 3802943>$

Zicoma. 1999. Les Zones d'Importance pour la Conservation des Oiseaux à Madagascar. Project ZICOMA. Antananarivo, Madagascar. 